\title{
EKSPRESI TINDAK DIREKTIF DALAM INTERAKSI KELAS BENGKEL JURUSAN TEKNIK MESIN POLITEKNIK NEGERI MALANG
}

\author{
Moh. Thamrin \\ Politeknik Negeri Malang \\ e-mail: thamrin.ham@gmail.com
}

\begin{abstract}
This study was a qualitative study employing the pragmatic approach. The subjects comprised the lecturer and students of the workshop class in the Department of Mechanical Engineering of the State Polytechnic of Malang. The data were collected through observations. The researcher was the key instrument, equipped with observation guides and an electronic recorder. The data were analyzed using the interactive analysis model by Miles and Huberman in three steps: (1) data reduction, (2) data display, and (3) conclusion drawing or verification. The results show that lecturer-student directive acts in the workshop class interaction are dominated by imperative sentences more than declarative and interrogative sentences. Studentlecturer directive acts are dominated by interrogative sentences. The functions of lecturer-student directive acts are more varied than those of student-lecturer directive acts. The request function in the lecturer-student interaction is the most dominant function among other functions. In the student-lecturer interaction, the command function is more dominant than the request function.
\end{abstract}

Keywords: directive acts, directive forms, directive functions

\section{PENDAHULUAN}

Interaksi kelas merupakan aktivitas berbahasa. Menurut Searle (1969:38) aktivitas berbahasa pada hakikatnya melaksanakan berbagai tindak bahasa sesuai dengan aturan penggunaan unsur-unsur bahasa. Tindakan itu misalnya, bertanya, memerintah, meminta tolong, dan berterima kasih. Selain itu dalam berbahasa, penutur tidak hanya dituntut untuk menggunakan bahasa yang gramatikal, tetapi juga dituntut menggunakan bahasa yang dapat diterima masyarakat tempat penutur melakukan aktivitas.

Seorang penutur bahasa Indonesia, tidak selalu menggunakan bentuk imperatif dalam menyuruh, tetapi dapat juga menggunakan bentuk deklaratif atau bentuk interogatif. Pemilihan terhadap satu formulasi kalimat di atas mengandung efek yang berbeda baik bagi penutur maupun petutur. Hal ini menandakan bahwa suatu bahasa tidak hanya berfungsi untuk mengungkapkan unsur kognitif saja, tetapi juga mengungkapkan unsur sikap yang ada dalam setiap bahasa. Dalam kondisi tertentu, unsur sikap tidak dinyatakan secara eksplisit oleh penutur, tetapi dapat dimengerti oleh petutur.

Tindak bahasa menurut Austin (dalam Gunarwan, 2007) memiliki makna yang dapat dibedakan menjadi tiga jenis, yaitu (a) tindak lokusi, (b) tindak ilokusi, dan (c) tindak perlokusi. Tindak lokusi adalah tindak bahasa yang berkaitan dengan pembentukan preposisi dan rujukan atau menunjuk pada makna harfiah. Dalam tindak ini penutur melakukan tindakan mengatakan sesuatu kepada petutur. Tindak ilokusi yaitu tindak yang menunjuk pada makna sebagaimana yang ditangkap oleh petutur. Dalam 
tindak ini penutur melakukan tindakan dalam mengatakan sesuatu kepada petutur. Sedangkan tindak perlokusi yaitu tindak yang mengacu makna yang diharapkan penutur. Dalam hal ini penutur memiliki harapan agar petutur dapat menangkap makna sebagaimana yang diharapkan.

Di antara ketiga macam tindak bahasa di atas, yang banyak mendapatkan perhatian para ahli filsafat dan ahli bahasa adalah tindak ilokusi. Searle (1976) mengklasifikasikan fungsi tindak ilokusi menjadi lima jenis, yaitu (1) tindak asertif, (2) tindak direktif, (3) tindak komisif, (4) tindak ekspresif, dan (4) tindak deklaratif. Kelima tindak ilokusi tersebut memiliki kaitan erat dengan interaksi kelas. Salah satu jenis tindak ilokusi yang berperan penting dalam interaksi kelas adalah tindak direktif, yakni tindak bahasa yang dilakukan penutur dengan tujuan menghasilkan suatu efek berupa tindakan yang dilakukan oleh petutur.

Salah satu setting kelas berada di level Politeknik. Dalam struktur pendidikan di Indonesia, Politeknik memiliki peranan yang sangat penting. Bahasa sebagai alat komunikasi dalam kegiatan ini menjadi sangat penting. Kesalahan penggunaan bahasa yang dilakukan di bengkel bukan saja menggagalkan tujuan yang ingin dicapai, tetapi juga akan berdampak pada rusaknya peralatan dan timbulnya kecelakaan fisik dan psikhis mahasiswa. Oleh karenanya, diperlukan kemampuan komunikasi yang memadai.

Kemampuan komunikasi menurut Cazden (1972:137) dan Canale (1983:1) secara garis besar terdiri atas 2 aspek yakni aspek kemampuan linguistik dan aspek kemampuan sosiolinguistik. Kemampuan-kemampuan itu didukung oleh empat hal, yaitu (1) kemampuan ketatabahasaan, (2) kemampuan sosiolinguistik, (3) kemampuan kewacanaan, dan (4) kemampuan strategi komunikasi. Keempat kemampuan ini yang menentukan komunikasi penutur dan petutur berhasil dengan baik.

Sejalan dengan uraian tersebut, penelitian dimaksudkan untuk mendeskripsikan bentuk dan fungsi tindak direktif dosen-mahasiswa dan mahasiswa-dosen dalam interaksi kelas bengkel Jurusan Teknik Mesin Politeknik Negeri Malang.

Penggunaan tindak direktif oleh dosen dalam interaksi kelas bengkel bertujuan (1) menciptakan suasana kelas agar mahahasiswa memiliki kondisi siap untuk memulai praktik, (2) mengembangkan interaksi kelas secara optimal, (3) menciptakan suasana lebih hidup dan dinamis, (4) menciptakan kontekstual yang tinggi karena mahasiswa dapat terlibat secara aktif dalam kegiatan pembelajaraan, dan (5) memperoleh balikan, seberapa banyak mahasiswa memperoleh keterampilan dalam proses pembelajaran.

Penggunaan tindak direktif oleh dosen dalam interaksi kelas bengkel adalah penggunaan bentuk bahasa untuk menyampaikan maksud agar mahasiswa melakukan sesuatu. Tindak direktif tersebut dapat dinyatakan dalam berbagai bentuk bahasa dan bergantung pada konteksnya. Konteks penentu dalam komunikasi secara nyata meliputi latar, pemeran-serta, tujuan, topik, nada, norma interaksi, dan ragam.

Tindak direktif juga dipakai oleh mahasiswa dalam interaksi kelas bengkel. Penggunaan tindak direktif oleh mahasiswa, dapat berfungsi sebagai pelatihan mengadakan negosiasi makna, menggunakan bahasa dengan konteks yang beragam, teknik mengatasi kesulitan, dan teknik pengembangan intelektual, emosional, serta moral.

Bahasa dapat dikaji dari bentuk (aliran formalisme) dan fungsi (aliran fungsionalisme). Leech (1983) menjelaskan bahwa penganut aliran formalisme 
cenderung menganggap: (1) hakikat utama bahasa adalah sebuah fenomena mental; (2) kesemestaan bahasa diturunkan dari warisan linguistik genetik yang dimiliki oleh manusia; (3) pemerolehan bahasa didasarkan pada kemampuan alamiah untuk belajar; dan (4) mengkaji bahasa sebagai suatu sistem yang otonom. Sebaliknya para fungsionalisme cenderung menganggap: (1) hakikat utama bahasa sebagai fenomena kemasyarakatan; (2) kesemestaan bahasa berasal dari kesemestaan yang ada dalam penggunaan bahasa masyarakat manusia; (3) pemerolehan bahasa didasarkan pada perkembangan kebutuhan dan kemampuan komunikatif dalam masyarakat; dan (4) mengkaji bahasa sebagai suatu sistem yang berhubungan dengan fungsi sosialnya. Pendapat ini sejalan dengan pendapat Fairclough (dalam Jorgensen dan Phillip, 2007:135) bahwa terdapat hubungan antara tatanan wacana dan konteks sosialnya.

Bentuk tindak direktif terdiri imperatif, deklaratif, dan interogatif. Kalimat imperatif mengandung maksud memerintah atau meminta agar mitra tutur melakukan sesuatu sebagaimana diinginkan si penutur. Kalimat deklaratif dalam bahasa Indonesia mengandung maksud memberitakan sesuatu kepada si mitra tutur. Kalimat interogatif adalah kalimat yang mengandung maksud menanyakan sesuatu kepada mitra tutur (Rahardi, 2008).

Fungsi tindak direktif itu sangat ditentukan oleh konteks situasi tutur yang melatarbelakanginya. Konteks yang dimaksud dapat bersifat ekstralinguistik dan dapat pula bersifat intralinguistik. Satu bentuk ujaran mempunyai beberapa fungsi, sebaliknya satu fungsi dapat dinyatakan, dilayani, atau diutarakan dalam berbagai bentuk ujaran (Blum-Kulka, dalam Gunarwan, 2007).

\section{METODE}

Penelitian ini termasuk jenis penelitian kualitatif yang menggunakan ancangan teori pragmatik. Teori pragmatik digunakan untuk memahami aspek-aspek pragmatik yang digunakan dosen dan mahasiswa dalam interaksi kelas.

Data penelitian ini berupa tuturan dalam interaksi kelas bengkel yang berkaitan dengan bentuk dan fungsi tindak direktif dan catatan lapangan tentang konteks komunikasi yang diperoleh dari hasil pengamatan peneliti di lapangan. Subjek penelitian ini adalah dosen dan mahasiswa di kelas bengkel Jurusan Teknik Mesin Politeknik Negeri Malang. Penentuan subjek penelitian ini didasarkan pada asas kecukupan data yang diperlukan dalam penelitian ini. Data yang berupa tuturan tindak direktif digunakan sebagai data utama yang dijadikan sebagai fokus analisis tuturan. Pengumpulan data dilakukan melalui observasi. Dalam pengumpulan data, peneliti sebagai instrumen kunci. Oleh karena itu, data dalam penelitian ini berupa perilaku komunikasi yang hanya dapat dipahami melalui interaksi antara peneliti dengan subjek dan faktor-faktor yang berperan dalam kegiatan berkomunikasi subjek. Instrumen tambahan yang digunakan adalah panduan pengamatan, alat bantu pengamatan berupa perekam elektronik, dan alat pencatatan lapangan.

Teknik pengumpulan data yang digunakan adalah teknik pengamatan. Pengamatan difokuskan pada kegiatan interaksi dosen-mahasiswa dan mahasiswa-dosen. Teknik pengamatan dilengkapi dengan pencatatan lapangan dan perekaman. Ketika mengumpulkan data, peneliti melakukan seleksi data dan klasifikasi data sesuai dengan masalah penelitian.

Analisis data penelitian ini menggunakan model analisis interaksi yang

Ekspresi Tindak Direktif dalam Interaksi Kelas Bengkel Jurusan Teknik Mesin Politeknik ... 
dikemukakan oleh Miles dan Huberman (1984) dengan langkah-langkah (1) reduksi data, (2) penyajian data, dan (3) simpulan atau verifikasi. Reduksi data mengacu pada proses menyeleksi, memfokuskan, menyederhanakan, mengabstraksikan, dan menstranformasikan data yang telah ditulis dari catatan lapangan atau transkripsi. Reduksi data merupakan sebuah bentuk analisis yang mempertajam, menyortir, memfokus, mengurangi, dan mengorganisasikan data sehingga simpulan akhir dapat dirumuskan dan diverifikasi. Penyajian data adalah menggabungan informasi yang telah diorganisasikan. Bentuk penyajian data dalam penelitian ini berupa teks naratif yang menggambarkan ekspresi bentuk verbal tindak direktif dan fungsi tindak direktif. Simpulan dan verifikasi merupakan alur penting ketiga dalam aktivitas analisis data. Diawali dengan koleksi data dan penentuan maknanya, kegiatan selanjutnya adalah menentukan simpulan secara jelas. Simpulan yang diambil diverifikasikan dengan diuji kebenarananya, kekuatannya, dan kesesuaiannya.

\section{PEMBAHASAN HASIL PENELITIAN} Bentuk Tindak Direktif Dosen-Mahasiswa dalam Interaksi Kelas Bengkel

Bentuk tindak direktif dalam interaksi kelas bengkel lebih didominasi oleh bentuk imperatif dibandingkan dengan bentuk deklaratif dan bentuk interogatif. Kondisi ini disebabkan dalam kegiatan pembelajaran di kelas bengkel bertujuan membentuk perilaku melalui pembiasaan-pembiasaan serta terjaminnya keselamatan dan kesehatan kerja. Hal tersebut dapat dicapai apabila tuturan yang disampaikan dosen kepada mahasiswa itu jelas dan mudah dipahami sehingga dosen cenderung menggunakan strategi instruksi dalam bentuk imperatif. Selanjutnya bentuk tindak di- rektif berupa imperatif, deklaratif, dan interogatif yang digunakan dapat dilihat pada contoh tuturan berikut.

(1) Frais bidang $A \pm 2 \mathrm{~mm}$ !

\section{Konteks:}

Dituturkaan oleh seorang dosen kepada mahasiswa ketika praktik mesin frais.

(2) Awas!

\section{Konteks:}

Tuturan dosen kepada mahasiswa ketika ada salah seorang mahasiswa akan memegang benda kerja yang sedang berputar padahal hal itu sangat membahayakannya.

(3) Benda kerja ini berposisi harus datar.

\section{Konteks:}

Dituturkan oleh dosen kepada mahasiswa ketika praktik kerja bangku. Dosen menyuruh mahasiswa agar membetulkan posisi benda kerja yang tidak datar.

(4) Kamu tidak menggunakan sepatu kulit.

\section{Konteks:}

Dituturkan oleh seorang dosen kepada salah seorang mahasiswa sambil memberi isyarat dengan jari telunjuknya menyuruh mahasiswa keluar/ tidak mengikuti praktik karena dalam kesepakatan, mahasiswa yang tidak memakai perlengkapan praktik tidak diperbolehkan mengikuti praktik.

\section{(5) Hasti, mana kacamatamu?}

\section{Konteks:}

Dituturkan oleh seorang dosen yang sedang jengkel dengan mahasiswa yang bernama Hasti yang tidak segera mengenakan kacamata praktiknya padahal mahasiswa yang lain sudah siap. 
(6) Dilihat, ada yang gelap?

Konteks:

Dituturkan oleh dosen kepada mahasiswa ketika praktik kerja bang$\mathrm{ku}$. Ia menunjukkan bagian yang gelap dan yang terang menggunakan pisau perata. Dosen menyuruh mahasiswa meratakan meratakan kembali.

\section{Bentuk Tindak Direktif Mahasiswa- Dosen dalam Interaksi Kelas Bengkel}

Bentuk tindak direktif yang digunakan dalam interaksi kelas bengkel dapat diklasifikasikan menjadi tiga macam, yakni (1) kalimat imperaktif, (2) kalimat deklaratif, dan (3) kalimat interogatif. Berdasarkan sebaran penggunaannya, bentuk tindak direktif didominasi oleh kalimat interogatif. Hal tersebut merupakan suatu strategi untuk memperoleh penguatan kompetensi yang harus dikuasai mahasiswa, juga dipengaruhi oleh posisi pemeran serta, yakni mahasiswa-dosen yang asimetris yang tidak memungkinkan mahasiswa menyuruh dosen dengan cara langsung. Bentuk tindak direktif dalam interaksi kelas bengkel antara mahasiswa-dosen, dapat dilihat pada contoh tuturan berikut.

(1) Pak, tolong ini belum bisa dinyalakan! Konteks:

Dituturkan oleh mahasiswa kepada dosennya pada saat ia tidak bisa menyalakan mesin dan meminta dosennya untuk membantu menyalakan.

(2) Pak, langkah berikutnya Pak!

Konteks:

Dituturkan oleh mahasiswa kepada dosen ketika meminta dosen untuk memberitahu langkah-langkah memasang sepatu pengikat rem.
(3) Cutting fluidnya habis, Bu.

\section{Konteks:}

Dituturkan oleh mahasiswa kepada dosen pada saat ia mendapati minyak yang ada di bak penampung habis dan meminta tolong dosennya untuk menyuruh teknisi mengisinya.

(4) Minyak remnya habis, Pak.

\section{Konteks:}

Dituturkan oleh mahasiswa kepada dosen ketika praktik otomotif. Mahasiswa mendapati minyak rem di tabung rem kosong dan minta dosen menyuruh bagian teknisi untuk mengisinya.

(5) Bu, punya saya lebih kasar kenapa?

Konteks:

Dituturkan oleh mahasiswa kepada dosen ketika ia meminta dosennya menjelaskan mengapa permukaan hasil praktik yang ia kerjakan terlihat kasar.

(6) Pisau fraisnya yang mana, Pak?

\section{Konteks:}

Dituturkan oleh seorang mahasiswa kepada dosen ketika minta informasi karena kesulitan menentukan ukuran pisau yang tepat.

\section{Fungsi Tindak Direktif Dosen-Maha- siswa dalam Interaksi Kelas Bengkel}

Fungsi tindak direktif dosen-mahasiswa dalam interaksi kelas bengkel adalah menyuruh, melarang, meminta, memohon, dan menyilakan. Fungsi tindak direktif dalam interaksi kelas bengkel didominasi oleh fungsi menyuruh dibandingkan dengan fungsi yang lain. Kondisi ini disebabkan dalam kegiatan pembelajaran di kelas bengkel bertujuan membentuk perilaku melalui pembiasaan-pembiasaan serta terjaminnya keselamatan dan kesehatan kerja. Hal tersebut dapat dicapai apabila tuturan 
yang disampaikan dosen kepada mahasiswa itu jelas dan mudah dipahami sehingga dosen cenderung menggunakan strategi instruksi dalam fungsi tindak direktif menyuruh atau memerintah. Penjelasan lebih lanjut mengenai kelima fungsi tersebut dapat dilihat pada pemerian di bawah.

\section{Menyuruh}

Tindak direktif yang digunakan dalam tindak direktif dosen-mahasiswa dalam interaksi kelas bengkel Jurusan Teknik Mesin yang berfungsi menyuruh atau memerintah dapat dilihat pada beberapa contoh tuturan berikut.

(1) Cek dulu perlengkekapan praktik Saudara! Cek dulu!

Konteks:

Tuturan seorang dosen kepada mahasiswa yang saat itu menjumpai beberapa mahasiswa yang belum menyiapkan perlengkapan alat praktik dan menyuruhnya untuk segera memeriksa perlengkapan praktiknya. Para mahasiswa memeriksa kembali perlengkapan praktiknya. Intonasi yang digunakan oleh dosen agak keras.

(2) Periksa ukuran benda kerja 20x32×123 $m m$ !

Konteks:

Tuturan seorang dosen kepada mahasiwa ketika mahasiswa harus memeriksa benda kerja sesuai dengan ukuran dan menyuruh mahasiswa mengganti apabila tidak sesuai dengan ukuran. Para mahasiswa segera mengukur ulang benda kerja yang sudah diterimanya. Intonasi yang digunakan oleh dosen agak keras.

Tuturan di atas, dianggap sebagai fungsi menyuruh ditandai dengan intonasi keras. Hal ini ditunjukkan dengan (1) konteks ketika tuturan itu diucap- kan dan adanya tuturan yang diulang kembali walau pun bentuknya lebih pendek; (2) didukung dengan kata kerja dasar (Ramlan, 1981: 20). Dalam bentuk direktif ditemukan tuturan imperatif yang hanya terdiri atas satu atau dua kata. Kalimat tersebut berupa kalimat lesapan situasional, yakni kalimat yang tidak dapat dimengerti maksudnya tanpa menelusur balik berdasarkan situasi atau konteksnya. Kalimat yang dimaksud terdapat dalam tuturan-tuturan yang berikut.

(3) Deburring!

\section{Konteks:}

Tuturan dosen kepada salah seorang mahasiswa ketika ia melihat benda kerja yang bagian-bagiannya masih tajam. Mahasiswa disuruh menumpulkannya bagian-bagian yang tajam itu dengan kikir.

\section{(4) Lepaskan!}

\section{Konteks:}

Tuturan dosen kepada mahasiswa ketika ia menyuruh mahasiswa melepas benda kerja dan mencekamkan kembali benda kerja dengan menggunakan pelindung plat pada bagian yang telah dikartel.

Di dalam interaksi kelas bengkel, fungsi menyuruh dapat diwujudkan pula dalam bentuk deklaratif. Fungsi menyuruh atau memerintah hanya dapat diketahui melalui konteks ketika tuturan itu diucapkan, seperti dapat dilihat pada tuturan dosen kepada mahasiswa berikut.

(5) Dosen: Ah, panas sekali ruang ini.

Mahasiswa: Ya Pak, saya nyalakan kipas anginnya.

\section{Konteks:}

Tuturan seorang dosen kepada mahasiswa di dalam ruang praktik pada saat ia akan memulai kegiatan praktik otomotif dan ruang praktik terasa panas. 
Di dalam interaksi kelas bengkel antara dosen-mahasiswa, fungsi menyuruh atau memerintah dapat pula diwujudkan dalam bentuk Interogatif. Tuturan dalam bentuk interogatif di bawah dapat diketahui memiliki fungsi menyuruh oleh petutur (mahasiswa) setelah memerhatikan konteks situasinya ketika tuturan itu diucapkan. Ini semua berarti berkaitan dengan maksud atau daya ujaran, seperti pada tuturan berikut.

(6) Diameternya berapa?

\section{Konteks:}

Tuturan dosen kepada mahasiswa ketika dosen menyuruh mahasiswa membuat lubang pada benda kerja dari bahan baja perkakas (tool steel) dengan diameter mata bor $15 \mathrm{~mm}$ berdasarkan gambar kerja yang telah ditunjukkan dosen kepada mahasiswa.

\section{Meminta}

Tuturan dalam bentuk imperatif yang mengandung fungsi meminta di antaranya terdapat pada tuturan-tuturan berikut.

(1) Tolong, lihat ini!

\section{Konteks:}

Tuturan dosen kepada mahasiswa ketika ia menunjukkan benda kerja yang baik dan yang tidak baik.

\section{(2) Tolong perhatikan!}

\section{Konteks:}

Tuturan dosen kepada mahasiswa ketika ia mengingatkan salah satu mahasiswa yang tidak memerhatikan

Tuturan di atas, dianggap sebagai fungsi meminta ditandai dengan kesantunan di antaranya tolong, coba, harap, mohon, dan ungkapan lain. Untuk memperjelas fungsi meminta tuturan di atas dapat diparafrasekan menjadi Saya meminta tolong agar melihat benda ini dan
Saya minta tolong kamu melihat saya. Dengan demikian, dapat dikatakan bahwa tuturan tersebut merupakan imperatif yang berfungsi meminta.

Diperoleh kenyataan pula dalam bentuk direktif ditemukan tuturan imperatif yang hanya dapat dimengerti maksud meminta dengan cara melihat konteknya, seperti pada contoh tuturan berikut.

\section{(3) Ditandai ya!}

\section{Konteks:}

Tuturan dosen kepada mahasiswa ketika ia meminta kepada mahasiswa untuk memberikan tanda pada benda kerja.

Di dalam interaksi kelas bengkel, fungsi meminta dapat pula diwujudkan dalam bentuk deklaratif. Fungsi menyuruh yang diwujudkan dalam bentuk deklaratif ini hanya dapat diketahui maksudnya melalui konteks ketika tuturan itu diucapkan, seperti dapat dilihat pada tuturan dosen kepada mahasiswa berikut.

(4) Benda kerja ini harus datar.

\section{Konteks:}

Tuturan dosen kepada mahasiswa agar mahasiswa mengatur kembali posisi benda kerjanya.

Tuturan-tuturan dalam bentuk deklaratif di atas dapat diketahui fungsi meminta setelah memerhatikan konteks situasinya ketika tuturan itu diucapkan. Tuturan di atas dipahami sebagai meminta oleh mahasiswa karena mahasiswa mengetahui (1) konteks yang mengacu kepada siapa bertutur, di mana, bilamana, untuk apa, dan bagaimana; serta (2) koteks, yang mengacu ke ujaran-ujaran sebelumnya yang mendahului dan atau yang mengikutinya.

Di dalam interaksi kelas bengkel, fungsi meminta dapat pula diwujudkan dalam bentuk interogatif. Bentuk interogatif ini hanya dapat diketahui 
fungsi menyuruhnya apabila memerhatikan konteks ketika tuturan itu diucapkan. Bentuk deklaratif yang berfungsi meminta dapat dilihat pada tuturan berikut.

(5) Ada kesulitan?

\section{Konteks:}

Tuturan dosen kepada mahasiswa pada saat akan mengakhiri kegiatan praktik. Mahasiswa diminta untuk mengutarakan hal-hal yang menjadi kendala waktu praktik.

\section{(6) Kenapa kok ngoyo?}

\section{Konteks:}

Tuturan dosen yang meminta salah seorang mahasiswa agar menggerakan kikir dengan santai.

Fungsi meminta dalam interaksi dosen-mahasiswa merupakan fungsi yang menduduki urutan kedua. Hal tersebut dapat dijelaskan bahwa kegiatan belajar-mengajar lebih banyak dilakukan dengan teknik penugasan atau instruksi. Dengan menggunakan fungsi meminta, suasana kelas menjadi kondusif. Mahasiswa merasa lebih nyaman karena dihargai.

\section{Memohon}

Tindak direktif dosen-mahasiswa dalam interaksi kelas bengkel yang berfungsi untuk memohon dapat dilihat pada tuturan di bawah.

(1) Mohon dicek lagi, mungkin ada peralatan yang kurang!

(Saya mohon dicek lagi, mungkin ada peralatan yang kurang.)

\section{Konteks:}

Tuturan dosen kepada mahasiswa agar mengecek kembali peralatan yang menjadi tanggung jawabnya.

Tuturan di atas, dianggap sebagai fungsi memohon ditandai dengan kesantunan mohon. Dalam penilitian ini diperoleh data bahwa pemarkah yang dipakai hanya satu yakni penggunaan kata mohon seperti yang dipakai dalam tuturan di atas. Untuk memperjelas fungsi memohon tuturan di atas dapat diparafrasekan menjadi tuturan deklaratif seperti yang tertulis di dalam kurung.

\section{Menyilakan}

Tindak direktif dosen-mahasiswa dalam interaksi kelas bengkel yang berfungsi menyilakan dapat dilihat pada tuturan berikut.

(1) Sekarang silakan berdiri di depan ragum!

\section{Konteks:}

Tuturan dosen kepada mahasiswa ketika ia menyilakan mahasiswa mengambil posisi di depan ragum.

\section{(2) Silakan berbaris!}

\section{Konteks:}

Tuturan seorang dosen kepada mahasiswa agar segera berbaris untuk diabsen dan sekaligus diperiksa kelengkapan kerja praktik yang digunakan.

Kalimat dalam tuturan di atas semuanya menggunakan bentuk imperatif dengan fungsi menyilakan. Fungsi menyilakan itu semakin jelas jika memerhatikan konteks sosialnya ketika tuturan itu diucapkan. Fungsi menyilakan ini dilakukan dosen dalam rangka menciptakan suasana kelas lebih kondusif.

\section{Melarang}

Tuturan yang berfungsi melarang dalam interaksi kelas bengkel antara dosen-mahasiswa dipaparkan sebagai berikut.

(1) Awas, bertahap, jangan langsung!

\section{Konteks:}

Tuturan dosen kepada mahasiswa agar melakukan pemotongan secara bertahap dan melarang pembubutan dengan pengurangan di- 
ameter yang besar. Diucapkan dengan intonasi tinggi dan cenderung terdengar membentak

(2) Pakai sikat! Pakai kuas! Jangan diketuk-ketukkan!

\section{Konteks:}

Tuturan dosen kepada mahasiswa ketika ia mengingatkan mahasiswa agar membersihkan beram/tatal (chip) dengan gunakan sikat atau kuas. Diucapkan dengan intonasi tinggi dan cenderung terdengar membentak

Tuturan di atas, dianggap sebagai fungsi melarang ditandai oleh pemakaian kata jangan dan awas. Tuturan di atas semakin jelas maknanya jika memerhatikan konteksnya. Tuturan dalam bentuk imperatif semakin dapat dipahami sebagai melarang karena (1) konteks yang mengacu kepada siapa bertutur, di mana, bilamana, untuk apa, dan bagaimana; serta (2) koteks, yang mengacu ke ujaran-ujaran sebelumnya yang mendahului dan atau yang mengikutinya.

\section{Fungsi Tindak Direktif Mahasiswa- Dosen dalam Interaksi Kelas Bengkel}

Urutan menggunaan fungsi tindak direktif mahasiswa-dosen dalam interaksi kelas adalah meminta dan menyuruh. Fungsi tindak direktif mahasiswa-dosen dalam interaksi kelas bengkel lebih didominasi oleh fungsi meminta dibandingkan dengan fungsi menyuruh. Hal tersebut selain merupakan suatu strategi untuk memperoleh penguatan kompetensi yang harus dikuasai mahasiswa, juga dipengaruhi oleh posisi pemeran serta, yakni hubungan mahasiswa-dosen yang asimetris. Posisi dosen dianggap lebih tinggi sehingga cenderung tidak memungkinkan mahasiswa menyuruh dosen dengan cara langsung.
Peran mahasiswa yang sangat berbeda dengan dosen memberi kemungkinan tidak banyak untuk menggunakan tindak direktif dalam berinteraksi dengan dosen. Dari segi situasi, tidak banyak motivasi yang menggunakan berbagai tindak direktif. Motivasi untuk menggunakan fungsi tindak direktif dalam interaksi dengan dosen lebih banyak sebagai strategi meminta bantuan untuk mengatasi hal-hal di luar kemampuannya atau meminta penguatan terhadap materi yang dipelajarinya. Selanjutnya kedua fungsi tindak direktif tersebut diuraikan sebagai berikut.

\section{Menyuruh}

Tindak direktif mahasiswa-dosen dalam interaksi kelas bengkel yang berfungsi menyuruh atau memerintah dapat dilihat pada contoh di bawah.

(1) Siap, berdoa mulai!

\section{Konteks:}

Tuturan ketua kelas pada saat ia memimpin doa ketika praktik bengkel mesin perkakas akan dimulai.

Fungsi menyuruh dalam bentuk imperatif semakin dapat dipahami dengan memerhatikan (1) konteks yang mengacu kepada siapa, di mana, bilamana, untuk apa, dan bagaimana; serta (2) koteks, yang mengacu ke ujaran-ujaran sebelumnya yang mendahului dan atau yang mengikutinya.

\section{Meminta}

Di dalam interaksi kelas bengkel, fungsi meminta menggunakan bentuk deklaratif seperti pada tuturan-tuturan di bawah.

\section{(1) Kurang satu Pak.}

\section{Konteks:}

Tuturan seorang mahasiswa kepada dosennya ketika pembagian benda kerja. Pada saat itu ada mahasiswa tidak mendapatkan bagian benda kerja meminta tolong dosen 
agar meyuruh teknisi menyiapkan satu benda kerja lagi untuk diberikan kepada satu mahasiswa yang belum mendapatkan bagiannya.

\section{(2) Berapa derajat Pak?}

\section{Konteks:}

Tuturan seorang mahasiswa kepada dosennya ketika mahasiswa menyetting eretan melintang pada posisi 0 derajat. Mahasiswa tidak tahu ukurannya.

Tuturan-tuturan di atas dapat diketahui memiliki fungsi meminta setelah memerhatikan konteks situasinya ketika tuturan itu diucapkan. Ini semua berarti berkaitan dengan maksud atau daya ujaran. Tuturan di atas dipahami sebagai meminta oleh dosen karena mengetahui (1) konteks yang mengacu kepada siapa bertutur, di mana, bilamana, untuk apa, dan bagaimana; serta (2) konteks, yang mengacu ke ujaran-ujaran sebelumnya yang mendahului dan atau yang mengikutinya.

\section{SIMPULAN}

Bentuk tindak direktif dosen-mahasiswa dalam interaksi kelas bengkel diklasifikasikan menjadi tiga macam kalimat, yakni (1) kalimat imperatif, (2) kalimat deklaratif, dan (3) kalimat interogatif. Kalimat imperatif paling dominan digunakan dalam interaksi kelas bengkel dibandingkan kalimat interogatif dan kalimat deklaratif. Kondisi ini disebabkan dalam kegiatan pembelajaran di kelas bengkel bertujuan membentuk perilaku melalui pembiasaan-pembiasaan serta terjaminnya keselamatan dan kesehatan kerja.

Bentuk tindak direktif mahasiswa-dosen dalam interaksi kelas bengkel lebih didominasi oleh kalimat interogatif dibandingkan dengan bentuk deklartatif dan interogatif. Hal tersebut selain merupakan suatu strategi untuk memperoleh penguatan kompetensi yang harus dikuasai mahasiswa, juga dipengaruhi oleh posisi pemeran serta, yakni mahasiswa-dosen yang asimetris. Dalam hal ini posisi dosen dianggap lebih tinggi sehingga cenderung tidak memungkinkan mahasiswa menyuruh dosen dengan cara langsung.

Fungsi tindak direktif dosen-mahasiswa dalam interaksi kelas bengkel lebih didominasi oleh menyuruh dibandingkan dengan fungsi yang lain. Kondisi ini disebabkan dalam kegiatan pembelajaran di kelas bengkel bertujuan membentuk perilaku melalui pembiasaan-pembiasaan serta terjaminnya keselamatan dan kesehatan kerja. Hal tersebut dapat dicapai apabila tuturan yang disampaikan dosen kepada mahasiswa itu jelas dan mudah dipahami sehingga dosen cenderung menggunakan strategi instruksi dalam tindak direktif dengan fungsi menyuruh.

Fungsi tindak direktif mahasiswadosen dalam interaksi kelas bengkel lebih didominasi oleh meminta dibandingkan dengan fungsi menyuruh. Hal tersebut selain merupakan suatu strategi untuk memperoleh penguatan kompetensi yang harus dikuasai mahasiswa, juga dipengaruhi oleh posisi pemeran serta, yakni hubungan mahasiswa-dosen yang asimetris. Dalam hal ini posisi dosen dianggap lebih tinggi sehingga cenderung tidak memungkinkan mahasiswa menyuruh dosen dengan cara langsung

Kegiatan belajar-mengajar di kelas bengkel bertujuan membentuk perilaku melalui pembiasaan-pembiasaan. Instruksi menggunakan bentuk direktif untuk mencapai tujuan itu perlu diperhatikan. Tuturan yang disampaikan oleh dosen harus jelas. Kejelasan instruksi ini akan menunjang kompetensi yang ingin dicapai. Selain daripada itu, instruksi yang jelas akan terjaminnya keselamat dan kesehatan kerja. 


\section{UCAPAN TERIMA KASIH}

Artikel ini diangkat dari tesis pada PPs Unisma tahun 2009. Ucapan terima kasih disampaikan kepada para dosen, istruktur bengkel, dan mahasiswa yang telah membantu pelaksanan pengumpulan data. Selanjutnya ucapan terima kasih disampaikan kepada redaktur ahli yang telah menelaah artikel ini

\section{DAFTAR PUSTAKA}

Canale, M dan Merrill Swain. 1983. Approaches to Communicative Competence. MEO Regional Language Center.

Cazden, C.B. 1972. Problem for Education: Language as Curriculum Content and Learning Environment; Child Language and Education. New York: Holt Rinehart and Winston.
Gunarwan, Asim. 2007. Pragmatik: Teori dan Kajian Nusantara. Jakarta: Penerbit Universitas Atma Jaya

Jorgensen, Marianne W. dan Louise J. Phillips. 2007. Analisis Wacana. Teori dan Metode. Yogyakarta: Pustaka Pelajar.

Leech. Geoffrey. 1983. Principles of Pragmatik. London: Longman.

Miles, Mattew B dan A Micheael Huberman. 1984. Qualitative Data Analysis. California: SAGE Publication.

Rahardi, R Kunjana. 2008. Kesantunan Imperatif Bahasa Indonesia. Jakarta: Penerbit Erlangga.

Ramlan. M. 1982. Ilmu Bahasa Indonesia: Sintaksis. Yogyakarta: UP Karyono.

Searle, JR. 1976. Speech Act: An Essay in the Philosophy of Language Cambridge: Cambridge U.P. 